\section{Spatial Field Survey of Cotton Whitefly and its Pupal Parasitism in Relation to Temperature and Humidity in Southern Pakistan}

\author{
Farhan Ahmad ${ }^{1, *}$, Muhammad Waris Sanjrani', Shah Nawaz Khuhro ${ }^{1}$, Asif Sajjad ${ }^{2}$, \\ Abid Ali ${ }^{3}$, Rashad Rasool Khan ${ }^{3}$, Farooq Ahmed ${ }^{3}$ and Junhe Liu ${ }^{4, *}$ \\ ${ }^{1}$ Entomology Section, Central Cotton Research Institute Sakrand, Shaheed \\ Benazirabad 67210, Sindh, Pakistan \\ ${ }^{2}$ Department of Entomology, University College of Agriculture and Environmental \\ Sciences, The Islamia University of Bahawalpur, Bahawalpur, Pakistan \\ ${ }^{3}$ Department of Entomology, University of Agriculture, Faisalabad 38000, Pakistan \\ ${ }^{4}$ Department of Biological Engineering, Huanghuai University, Zhumadian, Henan \\ 463000, China
}

\begin{abstract}
A B S T R A C T
Among abiotic factors, temperature and relative humidity are important factors for higher cotton yields in all cotton growing regions. Cotton whitefly (Bemisia tabaci G.) being vector of CLCuV in Pakistani cotton crop is responsible to cause an economic damage. A survey of whitefly populations and its parasitism with connection to temperature and relative humidity was conducted in fourteen cotton growing districts of Sindh province (southern Pakistan) for 2012 and 2013 seasons. There was a significant difference in whitefly population and percent parasitism among the fourteen districts. The highest average whitefly populationof two consecutive years was recorded in Khaipur, Sukhur, Sangar and Nausharo Feroze i.e. 7.5, 6.1, 5.6 and 5.5 individuals per leaf, respectively. While the lowest was recorded in Hyderabad (1.9) and Mirpurkhas (2.2). On the other hand, the highest percent parasitism was observed in Khaipur, Tando Muhammad Khan, Nausharo Feroze and Sangar i.e. 14.1, 10.5, 10.4 and 10.5 percent, respectively whereas the lowest percent parasitism was recorded in Hyderabad (5.8) and Matiari (5.9). The study regarding impact of abiotic factors on whitefly population and percent parasitism was carried out at Central Cotton Research Institute Sakrand in 2013. We observed positive relationship between the abundance of whitefly and percent parasitism; while both had a strong positive relationship with percent relative humidity and only a positive relationship with the average temperature. This study hopes to establish an understanding for cotton growers and researchers that how population of whitefly and its parasitism vary in relationship with abiotic factors among different cotton growing areas of Sindh province. Furthermore, this study could help in forecasting and monitoring of whitefly incidence and its parasitism.
\end{abstract}

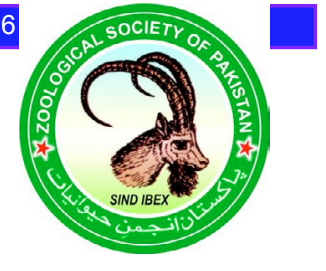

CrossMark

Article Information
Received 27 July 2017
Revised 01 January 2018
Accepted 19 February 2018
Available online 11 May 2018
Authors' Contribution
FA, MWS, AS and AA designed the
experiments. FA and SNK performed
the experiments. FA, AA, RRK,
Farooq A and JHL prepared the first
draft of manuscript, FA, AA and AS
analyzed the data. JL, AS and AA
modified the paper.
Key words
Abiotic factors, Cotton, Distribution,
Parasitism, Population, Whitefly.

Articie Information

Revised 01 January 2018

Accepted 19 February 2018

vailable online 11 May 2018

Authors' Contribution

, MWS, AS and AA designed the the experiments. FA, AA, RRK,

Farooq A and JHL prepared the first draft of manuscript, FA, AA and AS

modified the paper.

Parasitism, Population, Whitefly.

\section{INTRODUCTION}

$\mathrm{W}$ hitefly,Bemisia tabaci,G.(Homoptera:Aleyrodidae), a polyphagous agricultural pest of tropical and subtropical regions is responsible to causes economic losses worldwide by affecting numerous fiber, vegetable and ornamental crops (Cahill et al., 1996; Perring, 2001; Farghaley et al., 2014). It may results up to $50 \%$ reduction in the boll production and plant growth (Zia et al., 2013). In cotton (Gossypium hirsutum L.), the adults and nymphs of cotton whitefly cause severe physiological disorders

\footnotetext{
Corresponding authors: farhanmhanif7@gmail.com; liujunhe79@126.com

0030-9923/2018/0004-1231 \$ 9.00/0

Copyright 2018 Zoological Society of Pakistan
}

directly either through feeding on sap and reducing photosynthesis or indirectly through secreting honeydew and transmitting viral diseases (Ali and Aheer, 2007; John et al., 2007; Tayyib et al., 2014). Historically, its first outbreak occurred in major cotton growing districts of Pakistan before 1975 (Yunus et al., 1980) and it became a persistent pest of cotton in 1987 (Aslam et al., 2001). During 1996, it appeared in an epidemic form and resulted in a massive damage at Bahawalpur region of Punjab province of Pakistan (Aheer et al., 1999). Genetic diversity and distribution of cotton whitefly have been reported from different cotton growing districts of Punjab Province of Pakistan (Tayyib et al., 2014), yet there is need to explore it in Sindh province that contributes a lot in cotton production.

Cotton whitefly is attacked by a number of insect parasitoids including 34 species of Encarsia, 12 species 
of Eretmocerus, 2 species of Amitus and one species each of Methycus and Signiphora (Gerling et al., 2001). But Encarsia and Eretmocerus have great importance in terms of their relative abundance (Palaniswami et al., 2001). Btcotton has been available commercially in Pakistan since 2010 and to our knowledge, this is the first study conducted in Sindh province regarding the current status of cotton whitefly and its parasitism in relation to temperature and relative humidity. Temperature and relative humidity effect the prevalence and population fluctuation of cotton whitefly in a variety of ways (Aheer et al., 1994; Gupta et al., 1998; Umar et al., 2003; Shivanna et al., 2011; Zia et al., 2013). Whitefly populations have shown to have a positive relationship with temperature while a negative relationship with relative humidity (Arif et al., 2006; Ashfaq et al., 2010; Kalkal et al., 2013). Contrarily, a negative relationship of whitefly population with temperature while a positive relationship with relative humidity has also been reported (Ghafoor et al., 2011; Anjali et al., 2012; Sahito et al., 2012). The increase in both the temperature and relative humidity has also shown to have a positive effect on whitefly population (Pun and Darais-Wamy, 2000; Soomro et al., 2012). The knowledge of interactions between pest activity and abiotic factors helps in deriving predictive models that can aid in forecasting of pest incidence.

Keeping these facts in mind, present work was conducted to monitor and investigate the fluctuation in populations of cotton whitefly and its percent parasitism in relationship with temperature and relative humidity throughout the cotton growing districts of Sindh province of Pakistan.

\section{MATERIALS AND METHODS}

\section{Experimental fields}

The study on spatial distribution of whitefly infestation and its parasitism was conducted in fourteen different cotton growing districts of Sindh i.e. Shaheed Benazirabad, Umerkot, Tando Allahyaar, Badin, Thatta, Khaipur, Sukhur, Sangar, Nausharo Feroze, Tando Muhammad Khan, Mirpurkhas, Hyderabad, Matiari and Ghotki at weekly intervals from August to September during two consecutive crop growing seasons i.e. 2012 and 2013 (Fig. 1). Fifteen cotton plots (one acre each) were randomly selected in each district.

The impact of abiotic factors on whitefly population and its parasitism was studied at research farm of Central Cotton Research Institute Sakrand during the cotton growing season 2013. Cotton was planted in a compact block of 50 acres with row to row distance of $75 \mathrm{~cm}$. The data was taken with 7 days intervals from June to
November 2013.

\section{Sampling}

For recording whitefly population and its parasitism, twenty-five leaves were observed from upper, middle and bottom parts of the randomly selected plants. Leaves were gently turned over and the number of whitefly adults, healthy nymphs (crawler) and parasitized nymphs were recorded. Parasitism in cotton whitefly was recorded by visual observations for the presence of any black parasitized pupae (Antony et al., 2004).

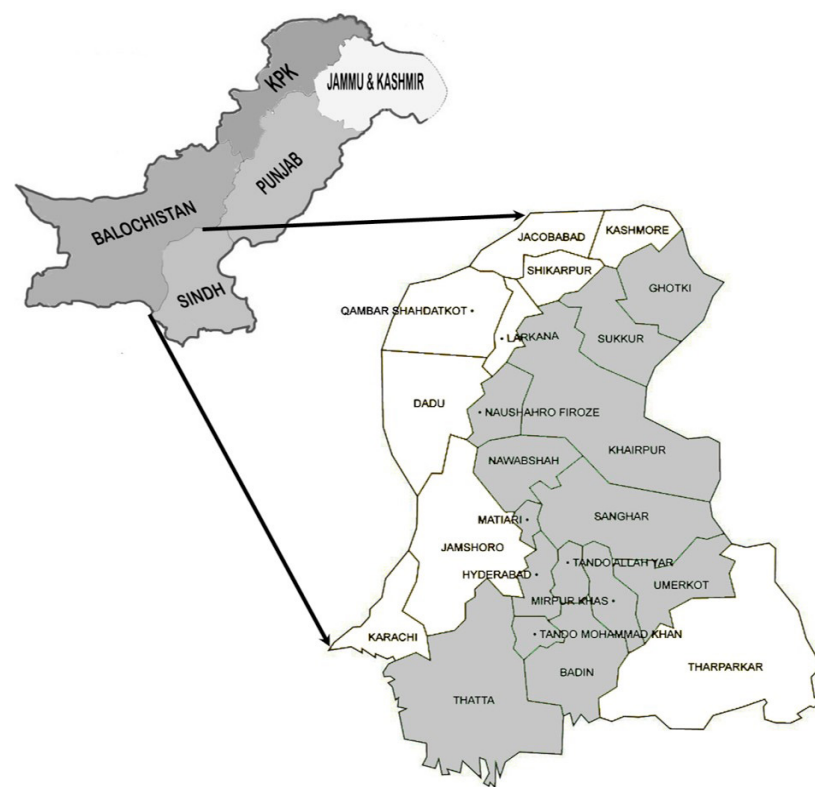

Fig. 1. Experimental study area of southern Pakistan. In the grey part of Sindh province, all experiment study areas have been mentioned by name.

Meteorological data (temperature and relative humidity) were recorded during each observation with the help of digital thermo-hygrometer (Hygrotherm, Model No. THC-03A). All agronomic practices of the cotton were followed according to local recommendations in which the experimental station is located. No pesticides were applied to the experimental fields.

\section{Statistical analysis}

Comparison of the data regarding pest population and percent parasitism in different districts of Sindh were made using a one-way analysis of variance (ANOVA) with the LSD test. A probability level of $P<0.05$ was considered as indicating statistical significance inside each district. Recorded numbers of adults and nymphs were pooled as total whitefly population. Agglomerative hierarchical 
clustering (AHC) analysis was used for relatedness among locations regarding whitefly population abundance and percent parasitism. Paired sample comparisons was used to compare the means of whitefly population and its percent parasitism of two consecutive years were made using test (t-test at alpha $=0.05)$. Simple linear regression analysis was carried out to determine the relationship of whitefly population and percent parasitism with abiotic factors (i.e. temperature and relative humidity). All statistical analyses were done using XLSTAT (2009) and Statistix (2003).

\section{RESULTS AND DISCUSSION}

There was a significant difference (d.f $=69, F=$ $196.56, P<0.001)$ in cotton whitefly population abundance and percent parasitism among different locations during 2012 (Table I). The highest population (6.83 per leaf) of whitefly was recorded at Khairpur while the lowest population was observed in Tando Muhammad Khan (1.65). Cotton whitefly parasitism during 2012 revealed that there was also a significant difference (d.f $=69, F=$ 415.23, $P<0.001)$ among different locations. The highest parasitism was recorded at Khairpur $(10.78 \%)$ while the lowest $(4.12 \%)$ was observed at Shaheed Benazirabad. There was also a significant difference (d.f $=69, F$ $=629.87, P<0.0001)$ in whitefly populations and its parasitism among different locations during 2013 (Table I). The highest whitefly population ( 8.12 per leaf) was recorded at Khairpur while the lowest (2.23) was recorded in Hyderabad. The percent parasitism during 2013 also revealed a significant differences (d.f $=69, F=1333.55, P<$ $0.0001)$ among different locations. The highest parasitism was recorded at Khairpur (18.04\%) while the lowest was observed at Matiari (4.33\%).

The variation in spatial distribution across spatial scale has widely been reported and several reasons have also been documented. Soberon (2010) perhaps has presented the most comprehensive account of his theoretical views in this regard. His framework encompasses three important elements i.e. (i) the abiotic factors that affect the net growth rate of population, (ii) the biotic factors that may affect the fitness in a regulatory manner and (iii) spatial movement related factors.

The t-test $($ Alpha $=0.05)$ analysis results showed that the overall whitefly population $4.51 \pm 0.46$ and percent parasitism $9.79 \pm 0.85 \%$ were significantly higher in 2013 as compared to 2012 (3.59 \pm 0.47 and $7.37 \pm 0.54 \%$, respectively) (Table II). Several studies have documented a number of reasons of such variation in pest populations across the scale and time e.g. variation in availability of alternate host plants or weeds (Zhang et al., 2013), variation in cropping intensity and pesticide application
(Trematerra et al., 2004), variation in availability of natural enemies and co-incidence in time with the pest population (Clark and Perry, 1994; Ali et al., 2016; Junhe et al., 2016) and variation in landscape structure beyond crop margins (Cronin and Reeve, 2005).

Table I.- Cotton Whitefly Population and percent parasitism on cotton crop in different districts of Sindh during 2012 and 2013.

\begin{tabular}{lccccc}
\hline District & \multicolumn{2}{c}{$\begin{array}{c}\text { Population of } \\
\text { Whitefly/leaf }\end{array}$} & & \multicolumn{2}{c}{$\begin{array}{c}\text { Whitefly } \\
\text { Parasitism (\%) }\end{array}$} \\
\cline { 2 - 3 } \cline { 5 - 6 } & $\mathbf{2 0 1 2}$ & $\mathbf{2 0 1 3}$ & & $\mathbf{2 0 1 2}$ & $\mathbf{2 0 1 3}$ \\
\hline Shaheed Benazirabad & $2.41 \mathrm{f}$ & $3.56 \mathrm{fg}$ & & $4.12 \mathrm{i}$ & $7.34 \mathrm{i}$ \\
Sanghar & $4.89 \mathrm{~d}$ & $6.23 \mathrm{c}$ & & $8.78 \mathrm{c}$ & $11.89 \mathrm{bc}$ \\
Umerkot & $3.18 \mathrm{e}$ & $3.41 \mathrm{~g}$ & & $4.67 \mathrm{~h}$ & $8.23 \mathrm{~h}$ \\
Mirpurkhas & $1.67 \mathrm{~g}$ & $2.78 \mathrm{~h}$ & & $8.34 \mathrm{~d}$ & $10.19 \mathrm{~d}$ \\
Tando Allahyar & $2.44 \mathrm{f}$ & $3.67 \mathrm{f}$ & & $5.23 \mathrm{~g}$ & $8.54 \mathrm{~g}$ \\
Matiari & $1.76 \mathrm{~g}$ & $3.45 \mathrm{~g}$ & & $7.41 \mathrm{ef}$ & $4.33 \mathrm{k}$ \\
Hyderabad & $1.75 \mathrm{~g}$ & $2.23 \mathrm{i}$ & & $4.69 \mathrm{~h}$ & $6.86 \mathrm{j}$ \\
Tando M. Khan & $1.65 \mathrm{~g}$ & $3.45 \mathrm{~g}$ & & $9.07 \mathrm{~b}$ & $11.93 \mathrm{~b}$ \\
Badin & $3.36 \mathrm{e}$ & $4.23 \mathrm{e}$ & & $7.15 \mathrm{f}$ & $10.09 \mathrm{de}$ \\
Thatta & $4.56 \mathrm{~d}$ & $4.69 \mathrm{~d}$ & & $9.16 \mathrm{~b}$ & $9.88 \mathrm{e}$ \\
Naushahro Feroze & $4.55 \mathrm{~d}$ & $6.34 \mathrm{c}$ & & $9.12 \mathrm{~b}$ & $11.66 \mathrm{c}$ \\
Khairpur & $6.83 \mathrm{a}$ & $8.12 \mathrm{a}$ & & $10.78 \mathrm{a}$ & $18.04 \mathrm{a}$ \\
Sukkur & $5.29 \mathrm{c}$ & $6.89 \mathrm{~b}$ & & $7.19 \mathrm{f}$ & $9.45 \mathrm{f}$ \\
Ghotki & $5.94 \mathrm{~b}$ & $4.08 \mathrm{e}$ & & $7.51 \mathrm{e}$ & $8.68 \mathrm{~g}$ \\
F & 196.56 & 629.87 & & 415.23 & 1333.55 \\
d.f & 69 & 69 & 69 & 69 \\
P & $<0.0001$ & $<0.0001$ & $<0.0001$ & $<0.0001$ \\
\hline
\end{tabular}

Table II.- Comparison of whitefly populations and parasitism during 2012 and 2013 (Mean \pm SE).

\begin{tabular}{lcc}
\hline Years & $\begin{array}{c}\text { Whitefly } \\
\text { population/leaf }\end{array}$ & $\begin{array}{c}\text { Parasitism } \\
(\%)\end{array}$ \\
\hline 2012 & $3.59 \pm 0.47$ & $7.37 \pm 0.54$ \\
2013 & $4.51 \pm 0.46$ & $9.79 \pm 0.85$ \\
Variance & 2.93 & 3.91 \\
Observations & 70 & 70 \\
Df & 69 & 69 \\
$\mathrm{t}$ Stat & -7.89 & -9.47 \\
$\mathrm{P}(\mathrm{T}<=\mathrm{t})$ two-tail & $<0.0001$ & $<0.0001$ \\
$\mathrm{t}$ Critical two-tail & 1.99 & 1.99 \\
\hline
\end{tabular}

The average relative humidity $(63.10 \%)$ during August and September of all locations was relatively higher in 2013 as compared to 2012 (i.e. 61.50\%) whereas, the average temperature was almost similar during the both years i.e. $30{ }^{\circ} \mathrm{C}$ in 2012 and $29.73^{\circ} \mathrm{C}$ in 2013 . 
In second experiment, the average temperature fluctuated between 20 to $33.50^{\circ} \mathrm{C}$ and relative humidity varied between 50.70 and $64.50 \%$ at Central Cotton Research Institute Sakrand, during June to November, 2013 (Fig. 2). The populations of cotton whitefly and its parasitism were only positively related with average temperature i.e. $\mathrm{y}=61.343+2.8552 \mathrm{x}, \mathrm{R}^{2}=0.1418$ and $\mathrm{y}=$ $-1.0819+.1758 x, \mathrm{R}^{2}=0.1549$, respectively. Whereas, both were strongly positively related with relative humidity $\mathrm{y}=-232.55+6.5528 \mathrm{x}, \mathrm{R}^{2}=0.8197$ and $\mathrm{y}=-18.952+0.3996 \mathrm{x}$, $\mathrm{R}^{2}=0.8776$, respectively (Table III).

Table III.- Relationships of whitefly population $s$ and its parasitism with abiotic factors at Sakrand during 2013.

\begin{tabular}{lcc}
\hline Regression equation & $\mathbf{R}^{\mathbf{2}}$ & $\mathbf{P}$ \\
\hline $\begin{array}{l}\text { Population of whitefly= } \\
\text { 61.34+2.85 (Temperature) }\end{array}$ & 0.142 & 0.46184 \\
$\begin{array}{l}\text { Percent parasitism }= \\
-1.082+.176 \text { (Temperature) }\end{array}$ & 0.154 & 0.44017 \\
$\begin{array}{l}\text { Population of whitefly }= \\
-232.55+6.554 \text { (Relative humidity) }\end{array}$ & 0.819 & 0.01300 \\
$\begin{array}{l}\text { Percent parasitism }= \\
-18.952+0.399 \text { (Relative humidity) }\end{array}$ & 0.877 & 0.00586 \\
$\begin{array}{l}\text { Population of whitefly }= \\
-4.253+0.057 \text { (percent parasitism) }\end{array}$ & 0.948 & 0.00101 \\
\hline
\end{tabular}

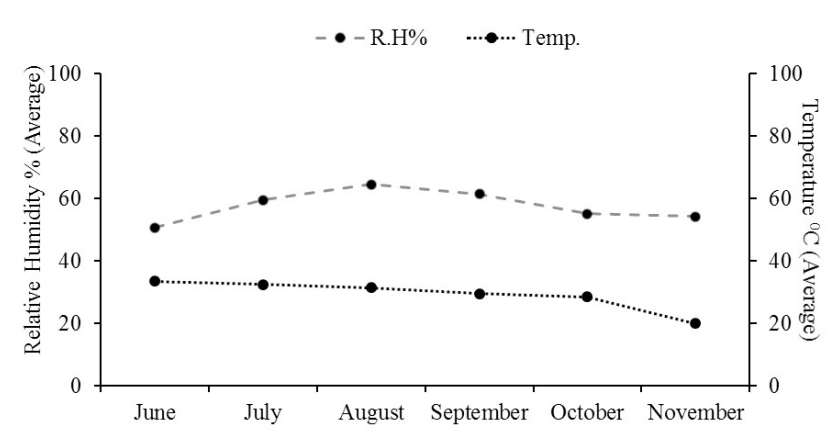

Fig. 2. Average temperature $\left({ }^{\circ} \mathrm{C}\right)$ and relative humidity $(\%)$ across the cotton growing season at Sakrand during 2013.

As many abiotic and biotic factors predict population dynamics of whitefly in an agricultural ecosystem. Therefore, it is usually hard to understand its relationship with temperature and relative humidity while ignoring other biotic and abiotic factors. The reason being different studies have shown different results. For example, Arif et al. (2006), Ashfaq et al. (2010) and Kalkal et al. (2013) reported a positive relationship of whitefly population with temperate while a negative relationship with relative humidity. On the other hand, Ghafoor et al. (2011), Anjali et al. (2012) and Sahito et al. (2012) reported a negative relationship of whitefly population with temperature while a positive relationship with relative humidity. Akram et al. (2013) has shown a positive relationship between whitefly population and temperature in BT cotton while it was negative in non-BT cotton. On the other hand, the relationship with relative humidity was negative in BT cotton while it was positive in non-BT cotton.

The results also revealed that there was a strong positive relationship between population of whitefly and percent parasitism $\left(\mathrm{y}=-4.2525+0.0574 \mathrm{x}, \mathrm{R}^{2}=0.9485\right)$. How natural enemies respond to variation in prey densities has been a subject of central theme in theoretical ecology. Natural enemies that respond numerically with prey are thought to be the ideal for biological control (Murdoch and Briggs 1996); however previous studies also show several inconsistencies in this regard. The possible explanation of such differences may include difference in the scale at which observations are made (Ray and Hastings, 1996), how the interacting populations being treated (e.g. as spatially homogenous) (Noda, 2004), behavioral differences among species (Peckarsky, 2006), availability of nesting places and food (Elliot and Kieckhefer, 2000).

\section{CONCLUSION}

Current study gives a brief account of how population of whitefly and its parasitism vary in relationship with abiotic factors among different cotton growing districts over two consecutive growing seasons. The maximum population of whitefly and percent parasitism was recorded in Khairpur during both the years while the minimum population of whitefly and percent parasitism varied among the locations i.e. Tando Muhammad Khan and Shaheed Benazirabad (for whitefly and parasitism, respectively) during 2012 and Hyderabad and Matiari during 2013. Moreover, the population of whitefly and its parasitism had no relationship with average temperature while they had strong positive relationship with percent relative humidity. Overall, this is a baseline study for future research in monitoring and IPM of whitefly.

\section{ACKNOWLEDGEMENTS}

This study was financially supported by the Central Cotton Research Institute Sakrand, Sindh province of Pakistan.

Statement of conflict of interest

Authors have declared no conflict of interest. 


\section{REFERENCES}

Aheer, G.M., Ghani, A. and Ali, A., 1999. Population of whitefly, Bemisia tabaci (Genn.) and its natural enemies on cotton crop at Bahawalpur. Pak. Entomol., 21: 47- 48.

Aheer, G.M., Ahmad, K.J. and Ali, A., 1994. Role of weather in fluctuating aphid density in wheat crop. J. agric. Res., 32: 295-301.

Akram, M., Hafeez, F., Farooq, M., Arshad, M., Hussain, M., Ahmed, S., Zia K. and Ali, A., 2013. A case to study population dynamics of Bemisia tabaci and Thrips tabaci on bt and non-bt cotton genotypes. Pak. J. agric. Sci., 50: 617-62 3.

Ali, A. and Aheer, G.M., 2007. Varietal resistance against sucking insect pests of cotton under Bahawalpur ecological conditions. J. agric. Res., 45: 1-5.

Ali, A., Desneux, N., Lu, Y., Liu, B. and Wu, K., 2016. Characterization of the natural enemy community attacking cotton aphid in the Bt cotton ecosystem in Northern China. Sci. Rep., 6: 24273. https://doi. org/10.1038/srep24273

Anjali, M., Singh, N.P., Mahesh, M. and Swaroop, S., 2012. Seasonal incidence and effect of abiotic factors on population dynamics of major insect pests on brinjal crop. J. environ. Res. Develop., 7: 431-435.

Antony, B., Palaniswami, M.S., Kirk, A.A. and Henneberry, T.J., 2004. Development of Encarsia bimaculata (Heraty and Polaszek) (Hymenoptera: Aphelinidae) in Bemisia tabaci (Gennadius) (Homoptera: Aleyrodidae) nymphs. Biol. Contr., 30: 546-555. https://doi.org/10.1016/j. biocontrol.2004.01.018

Arif, M.J., Gogi, M.D., Mirza, M., Zia, K. and Hafeez, F., 2006. Impact of plant spacing and abiotic factors on population dynamics of sucking insect pests of cotton. Pak. J. biol. Sci., 9: 1364-1369. https://doi. org/10.3923/pjbs.2006.1364.1369

Ashfaq, M., Noor-ul-Ane, M., Zia, K., Nasreen, A. and Hasan, M., 2010. The correlation of abiotic factors and physico-morphic characteristics of (Bacillus thuringiensis) Bt transgenic cotton with whitefly, Bemisia tabaci (Homoptera: Aleyrodidae) and jassid, Amrasca devastans (Homoptera: Jassidae) populations. Afr. J. agric. Res., 5: 3102-3107.

Aslam, M., Khan, A.H., Rasheed, T. and Khan, I.H., 2001. Monitoring whitefly, Bemisia tabaci (Genn.) on cotton. Pakistan J. Zool., 33: 261-264.

Cahill, M., Denholm, I., Ross, G., Gorman, K. and Johnston, D., 1996. Relationship between bioassay data and the simulated field performance of insecticides against susceptible and resistant adult Bemisia tabaci (Homoptera: Aleyrodidae). Bull. entomol. Res., 86: 109-116. https://doi.org/10.1017/ S0007485300052330

Clark, S.J. and Perry, J N., 1994. Small sample estimation for Taylor's power law. Environ. Ecol. Stat., 1: 287302. https://doi.org/10.1007/BF00469426

Cronin, J.T. and Reeve, J.D., 2005. Host-parasitoid spatial ecology: A plea for a landscape-level synthesis. Proc. R. Soc., 272: 2225-2235. https:// doi.org/10.1098/rspb.2005.3286

Elliott, N.C. and Kieckhefer, R.W., 2000. Response by coccinellids to spatial variation in cereal aphid density. Popul. Ecol., 42: 81-90. https://doi. org/10.1007/s101440050012

Farghaley, S.F., Hamama, H.M. and Dawood, A.E., 2014. Role of Cytochrome P450 gene in insecticide susceptibility of the whitefly, Bemisia tabaci (Homoptera, Aleyrodidae) in Egyptian governorates. Int. J. biol. Sci., 1: 62-71.

Gerling, D., Alomar, O. and Arno, J., 2001. Biological control of Bemisia using predators and parasitoids. Crop Prot., 20: 779-799. https://doi.org/10.1016/ S0261-2194(01)00111-9

Ghafoor, A., Hassan, M., Alvi, Z.H. and Kousar, S., 2011. Impact of different varieties of stub cotton on population dynamics of whitefly at Faisalabad, Pakistan. Pakistan J. Zool., 43: 25-28.

Gupta, G.P., Mahaputro, G.K., Kundu, S.K., Roshan, L. and Lal, R., 1998. Impact of abiotic factors on the population dynamics of whitefly in cotton. Indian J. Ent., 60: 207-296.

John, B., Darry, H. and Greg, P., 2007. Hort guard TM initiative AGWEST spiraling whitefly Aleurodicus dispersus exotic threat to Western Australia. Available at: http://www.agric.wa.gov.au/objtwr/ imported_assets/pw/fs01800.pdf

Junhe, L., MingFu, Y., Abid, A., Jia-Yang, L., Keming, L., and Niaz, H.K., 2016. Density estimation of ground-dwelling predators in wheat field of Northwest China. Pakistan J. Zool., 48: 481-487.

Kalkal, D., Lal, R., Dahiya, K.K. and Bharti, Y.P., 2013. Population dynamics of sucking pest and its correlation with abiotic factors. Agriways, 2: 3-29.

Murdoch, W.W. and Briggs, C.J., 1996. Theory for biological control: Recent developments. Ecology, 77: 2001-2013. https://doi.org/10.2307/2265696

Noda, T., 2004. Spatial hierarchical approach in community ecology: a way beyond low predictability of local phenomena. Popul. Ecol., 46: 105-117. https://doi.org/10.1007/s10144-0040184-x 
Palaniswami, M.S., Antony, B., Lisha,V.S. and Henneberry, T.J., 2001. Sweet potato whitefly Bemisia tabaci: ecobiology, host interaction and natural enemies. Entomon, 26: 256-262.

Peckarsky, B.L., 2006. Predator-prey interactions, Chapter 24 In: Methods in stream ecology (eds. R. Hauer and G. Lamberti), Second edition. Academic Press, NY.

Perring, T.M., 2001. The Bemisiata baci species complex. Crop Prot., 20: 725-737. https://doi. org/10.1016/S0261-2194(01)00109-0

Pun, K.B. and Darais-Wamy, S., 2000. Influence of weather factors on the incidence of okra yellow vein mosaic virus disease. J. Agric. Sci. Soc. N.E. India, 13: 19-96.

Ray, C. and Hastings, A., 1996. Density dependence: Are we searching at the wrong spatial scale? J. Anim. Ecol., 65: 556-566. https://doi.org/10.2307/5736

Sahito, H.A., Abro, G.H., Memon, S.A., Mal, B. and Mahmood, R., 2012. Influence of abiotic factors on population development of Bemisia tabaci infesting Abelmoschus esculentus. Int. Res. J. Pl. Sci., 3: 12-18.

Shivanna, B.K., Gangadhara N.B., Basavaraja, M.K., Nagaraja, R., Kalleswara S.C.M. and Karegowda, C., 2011. Impact of abiotic factors on population dynamics of sucking pests in transgenic cotton ecosystem. Int. J. Sci. Nature, 2: 72-74.

Soberon, J., 2010. Niche and area of distribution modeling: A population ecology perspective. Ecography, 33: 159-167. https://doi.org/10.1111/ j.1600-0587.2009.06074.x

Soomro, S.H., Sultana, R., Soomro, A.H., Solangi B.K. and Solangi, M.N., 2012. Studies on the distribution pattern of whitefly Bemisia tabaci Genn on okra crop in Sindh-Pakistan. Pak. J. Ent., 27: 111-116.

Statistix, 2003. Statistix $\AA^{8}$ Analytical software, user's manual. Tallahassee, pp. 396.

Tayyib, M., Suhail, A., Arif, M.J. and Khan, M.A., 2014. Whiteflies (Aleyrodidae: Homoptera) of Punjab, Pakistan. Pak. Entomol., 36: 31-34.

Trematerra, P., Paula, M.C.Z., Sciarretta, A. and Lazzari, S.M.N., 2004. Spatio-temporal analysis of insect pests infesting a paddy rice storage facility. Neotrop. Ent., 33: 469-479. https://doi.org/10.1590/ S1519-566X2004000400012

Umar, M.S., Arif, M.J., Murtaza, M.A., Gogi, M.D. and Salman, M., 2003. Effect of abiotic factors on the population fluctuation of whitefly, Bemisia tabaci (Genn.) in nectaried and nectariless genotypes of cotton. Int. J. Agric. Biol., 5: 362-368.

XLSTAT, 2009. XLSTAT software, version 9.0. Paris, France.

Yunus, M., Yousuf, M. and Gilani, G., 1980. Insect and spider mite pests of cotton in Pakistan. Final report P.L. 480 Project, Dept. Ent. Univ. Agric., Faisalabad, pp. 256.

Zhang, X., Yang, N., Wan, F. and Love, G.L., 2013. Density and seasonal dynamics of Bemisia tabaci (Gennadius) Mediterranean on common crops and weeds around cotton fields in Northern China. J. Integr. Agric., 13: 2211-2220. https://doi. org/10.1016/S2095-3119(13)60613-9

Zia, K., Hafeez, F., Bashir, M.H., Khan, B.S., Khan, R.R. and Khan. H.A.A., 2013. Severity of cotton whitefly (Bemisiata baci Genn.) population with special reference to abiotic factors. Pak. J. agric. Sci., 50: 217-222. 